8 cases fullfilled the criteria of $V A D$ insertion (C.I $<2.0$, LAP or RAP $>18 \mathrm{mmHg}$, SAOP $<90 \mathrm{mmHg}$ ) in ICU after operation

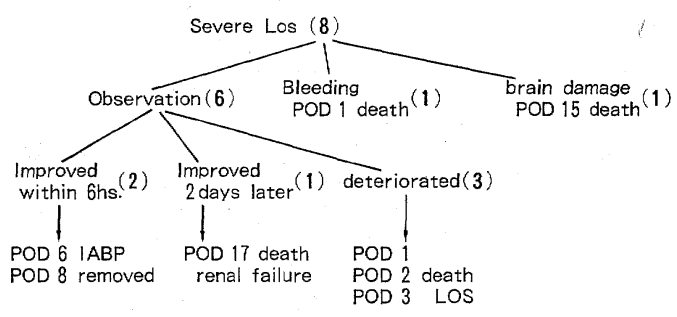

図 1 Postoperative LOS

した. VAD にても血行動態改善の得られなかった 3 例 は，両心不全と出血が加わっており，いずれも2 日以内 で死亡した．とくに症例 1 と症例 6 は両心バイパスの適 応であったと判断された。

\section{IABP 群}

この群のうち術後 ICU へ带室してから VAD 適 用基準 (心係数 $<2.0 \sim 2.2 \mathrm{l} / \mathrm{min} / \mathrm{m}^{2}$ ，心房圧 $>18 \sim 20$ $\mathrm{mmHg}$ ，収縮期血圧 $<90 \mathrm{mmHg}$ ）のうち二つ以上を満 たしたものが 8 例あった. 出血之脳梗塞の 2 例以外 6 例 を容量負荷とカテコラミンで経過観察した．とのうち 2 例は 2 6 時間で血行動態は改善し経過良好であった が，3例はそのまま LOS にて死亡し，残る 1 例は 2 日 後に心機能は改善するあ, 結局 MOF にて死亡した（図 1).また，心係数と心房圧はVAD 適用基準外である が収縮期血圧が低いすのは，血圧を上げることにより LOS が著明となる場合があった。

$$
\text { 考案 }
$$

$\mathrm{VAD}$ 適用基準としては各施設より種々のあのが出さ
れているが2-4), 心房圧 $18 \sim 22 \mathrm{mmHg}$ 以上，心係数 1.8 2. $2 \mathrm{l} / \mathrm{min} / \mathrm{m}^{2}$ 以下, 収縮期血圧 $80 \sim 90 \mathrm{mmHg}$ 以 下といったところが最大公約数であろう．しかし，現実 には体外循環離脱困難の症例が主とんごであり, 体外循 環時間を短くするためにも外科医の clinical impression を重視すべきである.

自験例では 11 例中 9 例が $\mathrm{CABG}$ 後で, しかも 6 例 が急性心筋梗塞後の心原性ショックによる緊急手術で あった.とういった症例を救命するには，現在のところ VAD で急性期を乗り切る以外方法はないであろう。ま た，右室梗塞を合併した場合，LVAD のみでいくか， RVAD+IABP あるいは BVAD が必要か, 議論のあ るところである.明らかに右心の壁運動不良を認めた 場合，RVAD は積極的に試みて良いと思われる ${ }^{5)} .15$ $\mathrm{mmHg}$ 以上の高い右房圧の持続は肝，腎化悪影響を与 え, 多臟器不全へ移行する可能性が高いと考えるべきで ある。

いったん体外循環より離脱して開胸後 LOS に陥った 場合, VAD を装着するために再び開胸するととに俊巡 してはならない，大量のカテコラミンで高い心房圧のま ま術後経過した症例の予後はきわめて不良である，最大 待って 6 時間，あるいはすっと早い時期で VAD 装着の 決断をすべきである.

文 献 1) Fukumasu, H. et al. : Jpn. J. Artif. Org. 15 : 473, 1986. 2) Richenbacher, W.E. et al. : Assisted Circulation 2, p. 70, Springer-Verlag, 1984. 3) Pennington, D. G. et al.: World J. Surg. 9: 37, 1985. 4) Fukumasu, H. et al.: Jpn. J. Artif. Org. 16 : 1145, 1987. 5) 畺根田純 一ほか：人工臟器 $16: 36,1987$.

148 急性右心不全時ならびに右心補助人工心蔵駆動時の 左心機能の検討

山口大学 第1外科
容 本 正 樹 西健 太郎 野 田 寛 森 文 樹
江 里 健 輔

最近, 右室梗塞や右室切開, 術後肺高血圧等の原因で 起こる急性右心不全に対し, 肺動脈バルーン ${ }^{1,2)}$ や右心 補助人工心臟 $(R V A D)^{3)}$ の効果が注目されつつある
が，急性右心不全時および機械的循環補助時の両室間の interaction はあまり知られていない，今回，実験的に 急性右心不全を作製し, RVAD 駆動と停止とが左心機 


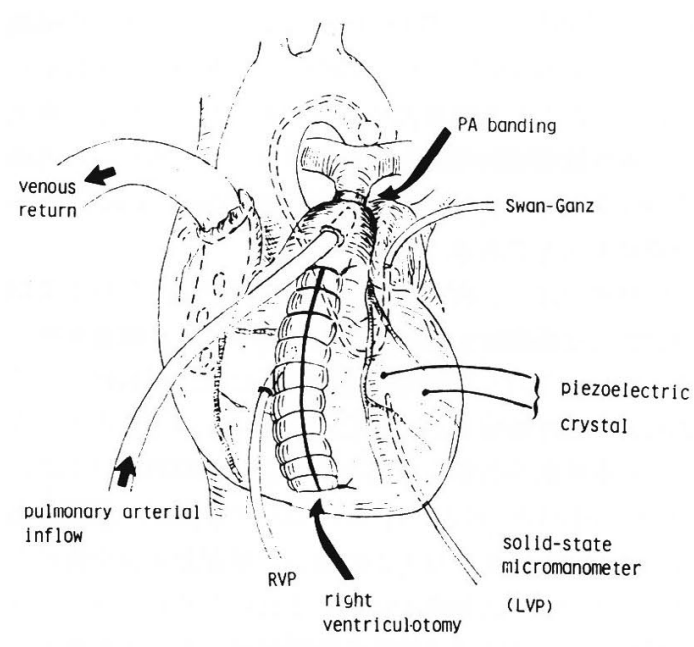

図 1 実験モデル

能に及ぼす影響について検討した。

\section{対象および方法}

雑種成犬 6 頭をペントバルビタール $(25 \mathrm{mmHg} / \mathrm{kg})$ による静脈麻酔下に気管内扱管し，人工呼吸下に左開胸 した. 左室の segment length 測定用に 1 対の超音波ク リスタルを左室前側壁に心臟長軸と直角方向に植えた. 心尖部より左室内に solid-state micromanometer を插 入し, 右室前壁より右室内に polyethylene catheter 㨂入した. 左心耳より左室を経て下行大動脈に Swan Ganz catheter を摴入した. 空気駆動ダイアフラム型補 助人工心臟を右房・肺動脈間飞装着し, 補助人工心臓駆 動装置モデル VCT-100 (東洋紡) 飞接続した. 急性右心 不全作製のため, 右室前壁をほぼ全長にわたって縦切開 した後縫合開鎖し，さらに肺動脈を右室圧が $50 \%$ 上昇 するまで絞扼した(図 1 )。右心不全作製後, RVADを 固定レート下最大流量で駆動させ循環を維持した。血 行動態の測定は, 右心不全作製前 (control)，作製後 (RVF)，および RVAD 駆動時 (RVAD) 飞, 安静時之 一時的な上行大動脈絞扼時に行った.

\section{結果}

心拍数は control 139/分, RVF 125/分, RVAD 128/ 分と, 全経過を通して有意に変化しなかった.

i ） RVF : 右室収縮期压 (RVSP) は, control の $27 \pm 11 \mathrm{mmHg}$ から $37 \pm 21 \mathrm{mmHg}$ と上昇したが有意 差はなかった. 右室拡張末期圧 (RVEDP) は control の $1.9 \pm 1.2 \mathrm{mmHg}$ 加 $6.3 \pm 1.0 \mathrm{mmHg}$ と有意に上

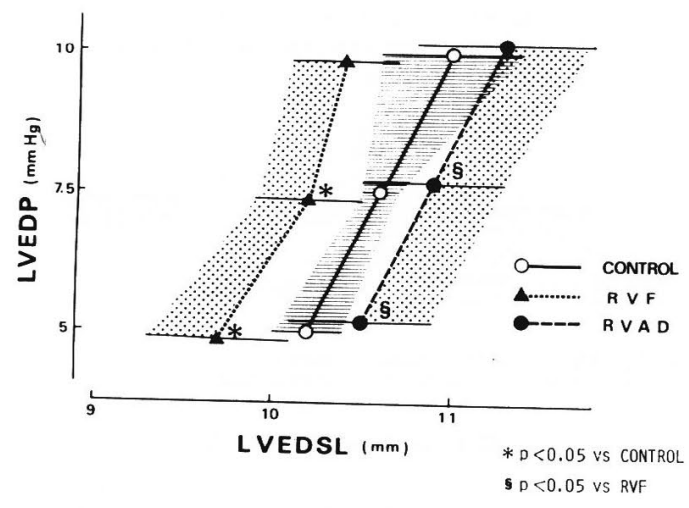

図 2 Left ventricular end diastolic pressure length curve

LVEDP : 左室拡張末期圧, LVEDSL : 左室拡張末期 segment length, Control: 右心不全作製前, RVF : 右心不全作製後, RVAD：RVAD 駆動時

昇した $(p<0.01)$. 左室拡張末期圧 (LVEDP) は 3.7 $\pm 0.8 \mathrm{mmHg}$ 加ら $2.3 \pm 1.0 \mathrm{mmHg}$, 左室収縮期圧 (LVSP) は $109 \pm 18 \mathrm{mmHg}$ から $75 \pm 13 \mathrm{mmHg}$, 心拍 出量 (CO) は $1.6 \pm 0.5 \mathrm{l} / \mathrm{min}$ 加ら $0.9 \pm 0.3 \mathrm{l} / \mathrm{min}$, \% systolic shortening (\% short) は $17 \pm 5 \%$ から $13 \pm$ $5 \%, \max \mathrm{LV} d$ dpldt $2500 \pm 500 \mathrm{mmHg} / \mathrm{s}$ から 1700 $\pm 400 \mathrm{mmHg} / \mathrm{s}$ とそれぞれ control と比べて有意に低 下した $(p<0.05)$. しかし $E_{\max }$ は $105 \pm 45 \mathrm{mmHg} / \mathrm{mm}$ から $102 \pm 32 \mathrm{mmHg} / \mathrm{mm}$ 之変化しなかった. 左室昖張 末期の左室圧/segment length 関係では, LVEDP が5, および $7.5 \mathrm{mmHg}$ の時 segment length (SL) は control の $10.2 \pm 0.2 \mathrm{~mm}, \quad 10.6 \pm 0.1 \mathrm{~mm}$ から RVF の $9.7 \pm 0.4 \mathrm{~mm}, 10.2 \pm 0.3 \mathrm{~mm}$ と有意に低下し $(p<$ $0.05)$, 圧/SL 関係曲線は control と比べて左方に移動 した (図 2). min LV dp/dt は $2400 \pm 1000 \mathrm{mmHg} / \mathrm{s}$ か ら $1200 \pm 300 \mathrm{mmHg} / \mathrm{s}$ と有意に低下した $(p<0.05)$ が, time constant (TC) は $30 \pm 3 \mathrm{~ms}$ 加ら $35 \pm 17 \mathrm{~ms}$ 之有 意な変化はなかった。

ii ）RVAD : RVSP は $22 \pm 8 \mathrm{mmHg}$ とRF と比べ て低下傾向があったが，有意差はなかった，RVEDP は $3.1 \pm 1.4 \mathrm{mmHg}$ と有意注下した $(p<0.01)$. LVEDP, CO, \% Short, $\max \mathrm{LV} d p / d t$ はそれぞれ $5.7 \pm 1.4$ $\mathrm{mmHg}, 110 \pm 24 \mathrm{mmHg}, 1.5 \pm 0.3 \mathrm{l} / \mathrm{min}, 19 \pm 6 \%$, $2400 \pm 400 \mathrm{mmHg} / \mathrm{s}$ と $\mathrm{RVF}$ と比べて有意に増加した $(p<0.01)$. しかし $E_{\max }$ は $100 \pm 52 \mathrm{Hg} / \mathrm{mm}$ と変化しな かった. 左室拡張末期の左室圧/SL 関係では, LVEDP が 5 および $7.5 \mathrm{mmHg}$ のとき SL は $10.9 \pm 0.4$ および $11.3 \pm 0.5 \mathrm{~mm}$ で, RVF と比べて有意に増加し $(p<$ 
表 1 Hemodynamic data

\begin{tabular}{|c|c|c|c|}
\hline & Control & $\mathrm{RVF}$ & RVAD \\
\hline $\begin{array}{l}\text { RVEDP } \\
(\mathrm{mmHg})\end{array}$ & $1.9 \pm 1.2$ & $6.3 \pm 1.0^{* *}$ & $3.1 \pm 1.4^{+}$ \\
\hline $\begin{array}{l}\text { RVSP } \\
(\mathrm{mmHg})\end{array}$ & $26.6 \pm 10.5$ & $36.6 \pm 20.9$ & $21.6 \pm 8.1$ \\
\hline $\begin{array}{l}\text { LVEDP } \\
(\mathrm{mmHg})\end{array}$ & $3.7 \pm 0.8$ & $2.3 \pm 1.0^{* *}$ & $5.7 \pm 1.4^{\dagger}$ \\
\hline $\begin{array}{l}\text { LVSP } \\
(\mathrm{mmHg})\end{array}$ & $109.1 \pm 18.1$ & $75.4 \pm 12.8^{* *}$ & $110.4 \pm 23.8^{+}$ \\
\hline $\begin{array}{l}\mathrm{CO} \\
(\mathrm{l} / \mathrm{min})\end{array}$ & $1.60 \pm 0.49$ & $0.92 \pm 0.30 *$ & $1.54 \pm 0.33^{\dagger}$ \\
\hline $\begin{array}{l}\text { \% Shortening } \\
\text { (\%) }\end{array}$ & $16.5 \pm 5.0$ & $12.8 \pm 5.0^{* *}$ & $19.3 \pm 6.0^{+}$ \\
\hline $\begin{array}{l}E_{\max } \\
(\mathrm{mmHg} / \mathrm{mm})\end{array}$ & $105 \pm 45$ & $102 \pm 32$ & $100 \pm 52$ \\
\hline $\begin{array}{l}\text { Time constant } \\
\text { (ms) }\end{array}$ & $30.0 \pm 3.3$ & $35.4 \pm 17.0$ & $38.4 \pm 5.5$ \\
\hline
\end{tabular}

$* p<0.05 ; * * p<0.01$ vs control,

$+p<0.01$ vs RVF, Mean \pm SD

0.05), 圧/SL 関係曲線は右方に移動した. $\min L V d p /$ $d t$ は $2000 \pm 600 \mathrm{mmHg} / \mathrm{s}$ と有意に増加した $(p<0.01)$ が, TC は $38 \pm 6 \mathrm{~ms}$ と有意な変化はなかった。

\section{考察}

右心機能は高肺血管抵抗下でとくに重要であり，右室 切開と肺動脈絞扼を伴ったわれわれのモデルでは著明な 心拍出量の低下と RVEDP の增加をきたし，右心不全 となった．右心拍出量の低下は肺静脈還流を低下させ， 左室の volume の低下をむたらした．また，右室は著
明に拡張し, 左室の geometry を変化させ左室拡張期の pressure/dimension 関係を左方に移動させた。両室間 の interaction や pressure/dimension 関係は心囊の 有無に大きく影響される れわれのモデルでも，急性右心不全により左室自由壁の pressure/dimension 関係は変化した. 急性右心不全時 の左心機能の低下は，乙うして起こった左室の filling の障害，すなわち左室拡張末期の心筋線維長の低下によ って生じ， $E_{\max }$ や TC で評価した左室自由壁の contractility や relaxation はよく保たれていた.

急性右心不全時の機械的循環補助手段として近年 PA バルーンが用いられてきた。 しかし強度の心不全では $\mathrm{PA}$ バルーンによる肺血流量の増加は不十分であり, RVAD のみが有効な循環補助手段となりうる 験でも, RVAD 駆動により左室前負荷は有意に増加し 左心機能は有意に改善された．同時に，変化した左室の geometry あ改善され, 左室拡張期の pressure/dimension 関係は右方に移動した. しかし，乙の間 $E_{\max } や$ TC には変化がなく, contractility と relaxation は一 定であった.

文 献 1) Miller, D.C. et al.: J. Thorac. Cardiovasc Surg. 89: 769, 1980. 2) Jett, G. K. et al.: J. Thorac. Cardiovasc. Surg. 92: 272, 1986. 3) Dembitsky, W.P. et al.: J. Thorac. Cardiovasc. Surg. 91: 518, 1986. 4) Misbach, G. A. et al.: Am. J. Physiol. 237: H644, 1979. 5) Gaines, W. E. et al. : J. Thorac. Cardiovasc. Surg. 88 : 958, 1984.

149 左心補助人工心臓の心負荷軽減効果が正常左室 心筋組織形態に及ぼす影響

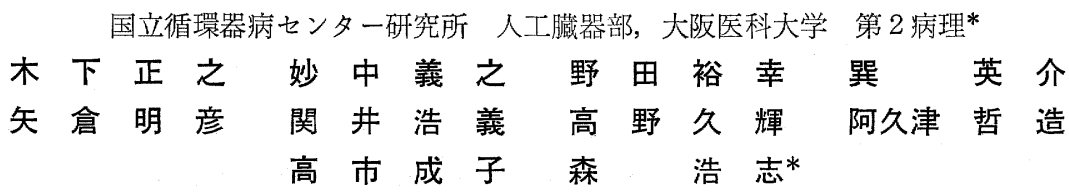

梗塞心がポンプ機能を回復する機序としては，虚血境 界領域の回復扝よび梗塞領域の線維化とともに, 正常 心筋の代償肥大が重要な要素となる．左心補助人工心臓 (LVAD) の屯つ心負荷軽減効果は，虚血璄界領域およ び梗塞領域の回復促進のためには有効であるととが多数
の研究から証明されてきた ${ }^{11}$. しかし正常心筋の代償肥 大に関しては，LVAD で長期間心負荷を軽減すれば 逆に代償肥大を抑制する可能性が考えられる．本研究で は，LVAD を長期間使用した場合の左室心筋組織形態 の変化を形態計測学的手法により計測し，正常心筋に退 